\title{
UNIVERSITY OF JURISPRUDENCE
}

By Sylvanus Morris, Dean of the Law Department, University of Georgia.

"Jurisprudence is the philosophy of law, the science which treats of the principles of positive law and legal relations. It is that science which has for its function to ascertain the principles on "which legal rules are based, so as not only to classify those rules in their proper order, and show the relation in which they stand to one another, but also to settle the manner in which new or doubtful cases should be brought under the appropriate rules. It is more a formal than a material science."

All law schools teach the principles of legal science, and to that extent are schools of jurisprudence. As the greater number of law students are prospective practitioners, the teaching necessarily has the practice in view. The time has not arrived, when a school of pure jurisprudence, for the academic, philosophical study of the science for learning's sake can be maintained. But the time is ripe for the establishment of such a school to meet needs now existent in our country. The advantages of a training in such a school to judges and practitioners are apparent and need not be discussed.

Our civilization has reached that degree of maturity, where specialization is demanded, special training for the work in hand is imperative. However much we may think that it is not consonant with our theory of government, the fact remains that politics is now a profession. In our system of government lawmakers ought not to be a class apart, but it is the condition not the theory with which we must deal. The need then for a school of jurisprudence, where men, who intend to devote their lives to public affairs, may receive the absolutely necessary training, seems indisputable. If judges and practitioners need training in those principles of law which underlie all good laws to fit them for their work, how much more is that training necessary to the law maker?

A thorough knowledge of the functions of government, of any and all forms and varieties; an acquaintance with the methods adopted by other countries in dealing with problems of government and legislation; a systematic study of the sociological con- 
ditions of our own and other countries should at least be the foundations of the education of a statesman.

Further, the most cursory acquaintance with the statutes, Federal and State, discloses the existence of numerous inharmonious, contradictory regulations. Leaving out of consideration the "freak legislation", the statutes confusedly framed, often ungrammatical, and not mentioning the expense and time required for the courts to explain and search out the legislative intent, we find the body of statute law is not infrequently a patchwork of temporary expedients. A single instance illustrates the point. Every statute repeals conflicting laws. It is sometimes an almost endless task to determine what laws and parts of laws are repealed through conflict, and what laws are not in conflict. The legal fabric should be an harmonious expression of the needs of the State and people.

Were it possible then to submit proposed legislation to a group of students of jurisprudence many of these defects would be avoided, and the saving in time and money (to put it on the lowest ground) would be incalculable. Having in mind the whole body of the law of the State, the laws in force on the particular subject, and the needs, activities, genius of the people of the State, a beginning might be made for framing a philosophical statute, founded on principle, clearly expressed, meeting the conditions and harmonizing with all parts of the body of the law. The proposed legislation could be subjected to the test of historical comparison with similar institutions in all countries, ancient and modern. Some such system of scrutiny as here indicated would soon bear fruit in symmetrical bodies of laws adapted to the needs of the social organism.

Another thought is suggested. Some States have codified their laws, others have made what are called codes, and others have digests. Were these codes, so-called codes and digests written by men trained in jurisprudence and not by committees of eminent practitioners, the result would justify the maintenance of a school of students devoting their lives to the research examination of legal principles. The harmonizing of laws with law is a need which to-day calls for the work of specialists.

A group of scholars, engaged in the study of jurisprudence, located at the capital, associated with the law schools now in existence in the States would be a long step toward the establishment of the University of Jurisprudence.

A thens, Ga. 